\title{
Quality of bronchial biopsies for morphology study and cell sampling: A comparison of asthmatic and healthy subjects
}

\author{
Isabelle Labonté $\mathrm{MSc}^{1}$, Michel Laviolette $\mathrm{MD}^{1}$, Ron Olivenstein $\mathrm{MD}^{2}$, Jamila Chakir $\mathrm{PhD}^{1}$, \\ Louis-Philippe Boulet MD1, Qutayba Hamid MD PhD²
}

I Labonté, M Laviolette, R Olivenstein, J Chakir, L-P Boulet, Q Hamid. Quality of bronchial biopsies for morphology study and cell sampling: A comparison of asthmatic and healthy subjects. Can Respir J 2008;15(8):431-435.

BACKGROUND: Bronchial biopsies are widely used for histopathological, primary cell culture and genetic studies, but very few reports have evaluated their quality.

OBJECTIVES AND METHODS: The present project evaluated the quality (using a scoring system) and the general morphology of a pool of six bronchial biopsy specimens taken from three different sampling sites (the lobar, segmental and subsegmental carinae) in 27 subjects (13 asthmatic subjects and 14 healthy controls). The present study also assessed quantitative measurements of structural changes related to asthma.

RESULTS: In total, $94.4 \%$ of the biopsy attempts had enough tissue to be processed. From these, $61.7 \%$ were scored with a good to excellent quality, while $76.5 \%$ presented smooth muscle bundles and $40.5 \%$ had an intact epithelium wall. The data also confirmed the structural changes observed in asthma, such as increased apparent thickening of the basement membrane, reduced amounts of smooth muscle for healthy controls and decreased percentage of intact epithelium for asthmatic subjects.

CONCLUSION: A pool of six bronchial biopsy specimens can provide tissue of excellent quality in both asthmatic and healthy subjects and, consequently, a valuable sample for morphological analysis of mucosal structures.

Key Words: Asthma; Bronchial biopsies; Morphology; Quality; Smooth muscle content

Q ronchial biopsy specimens obtained by bronchoscopy proBide a very useful and safe tool to study cellular, immunological and molecular abnormalities of the airway mucosa in asthma and related diseases (1-4). The size and quality of the biopsy specimens have major affects on the assessment of morphological and histopathological features (5). They also have critical consequences for the primary culture of epithelial, fibroblast (6) and smooth muscle (SM) cells (7), and for genetic studies (8). Many factors are involved in determining the quality of the biopsy specimens, including the type of forceps, the sampling sites, the number of samples and the experience of the operator. However, there are very few reports that have examined these issues systematically.

A previous publication (5) has reported an accurate method of analysis for endobronchial biopsies in health and disease. Briefly, quality biopsy specimens must be composed of

\section{La qualité des biopsies bronchiques pour les études de morphologie et les échantillons de cellules : Une comparaison entre des sujets asthmatiques et en santé}

\begin{abstract}
HISTORIQUE : Les biopsies bronchiques sont généralisées pour les études histopathologiques, génétiques et de cellules primaires, mais très peu de rapports en évaluent la qualité.

OBJECTIFS ET MÉTHODOLOGIE : Le présent projet visait à évaluer la qualité (au moyen d'un système de pointage) et la morphologie générale d'un groupe de six spécimens de biopsie bronchique prélevés dans divers sites de prélèvements (les carènes lobaire, segmentaire et sous-segmentaire) de 27 sujets (13 sujets asthmatiques et 14 sujets témoins). La présente étude a également servi à évaluer des mesures quantitatives de changements structurels reliés à l'asthme.

RÉSULTATS : Au total, 94,4 \% des tentatives de biopsie contenaient assez de tissus pour être traitées. De ce nombre, $61,7 \%$ obtenaient une évaluation de bonne à excellente qualité, tandis que $76,5 \%$ comportaient des faisceaux de muscles lisses et 40,5\%, une paroi épithéliale intacte. Les données ont également confirmé les changements structurels observés dans l'asthme, tels qu'une augmentation de l'épaississement apparent de la couche basale, une moins grande quantité de muscle lisse chez les sujets en santé et une diminution du pourcentage d'épithélium intact chez les sujets asthmatiques.

CONCLUSIONS : Un groupe de six spécimens de biopsie bronchique peut fournir des tissus d'excellente qualité tant chez les sujets asthmatiques que chez les sujets en santé et, par conséquent, un échantillon utile d'analyse morphologique des structures muqueuses.
\end{abstract}

a subepithelial area (without crushed artefacts, cartilage and blood clots) of $0.3 \mathrm{~mm}^{2}$ to $0.5 \mathrm{~mm}^{2}$, and sampling and analysis should be randomly performed. This randomness will reduce the variability and maximize the accuracy of the final observations (5).

Asthma is characterized, in part, by structural changes (also known as remodelling) of the bronchial mucosa (9). The mechanisms leading to remodelling in asthma are not totally understood, but the structural changes have been widely reported and include the following: an increase in SM mass, subepithelial fibrosis (apparent thickening of the basement membrane $[\mathrm{BM}])$, epithelial shedding and increased amounts of mucous glands within the bronchial wall $(10,11)$.

The aim of the present study was to evaluate the quality of bronchial biopsy samples taken from a pool of six bronchial biopsy specimens from mild to moderate asthmatic and healthy 
TABLE 1

Clinical characteristics of study participants

\begin{tabular}{|c|c|c|}
\hline & $\begin{array}{l}\text { Asthmatic subjects, } \\
n=13\end{array}$ & $\begin{array}{c}\text { Healthy controls, } \\
n=14\end{array}$ \\
\hline Age (range), years & $27.1(18-45)$ & $29.4(19-51)$ \\
\hline Sex (male/female) & $7 / 6$ & $9 / 5$ \\
\hline FVC, L & $4.3 \pm 0.9$ & $4.8 \pm 0.8$ \\
\hline FVC, \% predicted & $94.7 \pm 13.1$ & $101.4 \pm 10.8$ \\
\hline $\mathrm{FEV}_{1}, \mathrm{~L}$ & $3.3 \pm 0.7^{\dagger}$ & $4.0 \pm 0.6$ \\
\hline $\mathrm{FEV}_{1}, \%$ predicted & $87.1 \pm 12.9^{\dagger}$ & $101.0 \pm 10.3$ \\
\hline $\mathrm{PC}_{20}, \mathrm{mg} / \mathrm{mL}$ & $2.2 \pm 2.1^{\dagger}$ & $164.6 \pm 93.9$ \\
\hline Atopy* & yes & no \\
\hline
\end{tabular}

Data are expressed as mean \pm SEM, unless otherwise indicated. *Atopy was assessed using the skin prick test: response read at $10 \mathrm{~min}$, a wheal response to histamine of $3 \mathrm{~mm}$ or greater served as a positive control, and sterile water as a negative control; ${ }^{\dagger}$ Statistically different from the healthy controls $(P<0.01)$ using the Student's test. FEV 1 Forced expiratory volume in $1 \mathrm{~s}$; FVC Forced vital capacity; $P C_{20}$ Provocative concentration of methacholine causing a $20 \%$ fall in FEV 1

subjects, according to specific criteria. We also aimed to corroborate these findings with quantitative assessment of structural changes observed in asthma. These qualitative and quantitative features were evaluated according to three different sampling sites: the lobar, segmental and subsegmental carinae.

\section{METHODS}

\section{Selection of study participants}

Healthy controls without a history of allergy or asthma, and subjects with mild to moderate asthma meeting the criteria of the American Thoracic Society for the diagnosis of asthma, were recruited (12). The healthy subjects $(n=14)$ did not take any medication in the previous three months and had no disease. For the asthmatic subjects $(n=13)$, the inclusion criteria were stable asthma treatment for at least three months, use of short-acting beta 2 -agonists on demand only, no use of antiinflammatory antiasthmatic drugs, no use of any other drugs and no diseases other than asthma. All subjects were nonsmokers and had no documented viral or bacterial infection within the two months preceding the bronchoscopy. All subjects gave informed consent for the study. The asthmatic subjects had to have a forced expiratory volume in $1 \mathrm{~s}$ of greater than $75 \%$ of the predicted value before undergoing bronchoscopy (Table 1). No short-acting beta ${ }_{2}$-agonists were given before the procedure.

\section{Bronchoscopy}

Bronchoscopy was performed under $\mathrm{O}_{2}$ at $5 \mathrm{~L} / \mathrm{min}$ by nasal catheter. After local anesthesia with $2 \%$ and $4 \%$ xylocaine, the flexible fibre optic bronchoscope (Olympus 200 P200 [Olympus America Inc, USA] with a $2.0 \mathrm{~mm}$ diameter channel) was introduced and tissue samples were taken. Sedation was given if the bronchoscopist judged that it was required. Vital signs, electrocardiograph output and oximetry were recorded throughout the procedure. The subjects were kept under observation until their condition was considered to be acceptable to leave by the bronchoscopist. The 27 volunteers were recruited from two centres.

\section{Bronchial biopsy technique}

An important issue for the interpretation of bronchial biopsy studies is tissue injury (cough and bronchial trauma) that may
TABLE 2

Sampling sites of the six bronchial biopsies attempted in each subject

\begin{tabular}{lllc}
\hline Biopsy & Sampling site & Bronchial level & $\begin{array}{c}\text { Generation } \\
\text { of bronchi }\end{array}$ \\
\hline I & Middle lobe & Lobar & 3rd \\
II & Middle lobe & Lobar & $3 \mathrm{rd}$ \\
III & Upper lobe & Segmental & 4 th \\
IV & Apical lower lobe (right or left B6) & Segmental & 4 th \\
V & Apical lower lobe (right or left B6) & Segmental & 4 th \\
VI & Basal pyramid of lower lobe & Subsegmental & 5 th \\
\hline
\end{tabular}

occur during the fibre optic bronchoscopy procedure, and during the handling of the samples with forceps (get a gentle but good grip of the samples on the first attempt). Also, very gentle manipulation of the samples from the forceps to vials is required. To minimize these artefacts, at each centre (Hôpital Laval and Montreal Thoracic Institute), all bronchoscopy procedures were performed by the same experienced bronchoscopist (Michel Laviolette and Ron Olivenstein, respectively) surrounded by the same research team. Six biopsy samples were taken according to the locations presented in Table 2. Alligator jaw forceps (FB-15C-1, Olympus, USA) were used at both centres. The volume of the forceps is $2.89 \mathrm{~mm}^{3}$, data provided by the manufacturer. All biopsy specimens were taken at the origin of the bronchial subcarina. Forceps were used for bronchial biopsies, as is usually done for tumour biopsies, ie, cups were closed on the tissue, held approximately $5 \mathrm{~s}$ and pulled up to tear/cut a piece of bronchial tissue. The bronchoscopists took the biggest piece of tissue possible from each selected site on the first attempt. When it was not possible to get an acceptable sample at a specific site, this procedure was considered to be a failure of the technique and was included in the results as such.

\section{Tissue processing}

When the forceps were withdrawn from the bronchoscope, the biopsy specimens were harvested with one side of a small forceps, without pinching. Slowly, and with a gentle movement, the arm of the forceps went under the biopsy sample and removed it from the side of the forceps. The biopsy samples were immediately placed into $4 \%$ freshly defrosted paraformaldehyde. The biopsy samples were kept at $4^{\circ} \mathrm{C}$ for less than $24 \mathrm{~h}$. They were then transferred to a cassette and placed in $10 \%$ formalin for a minimum of $2 \mathrm{~h}$. The cassette was then placed in a circulating vacuum unit overnight (approximately $14 \mathrm{~h}$ ); thereafter, the bronchial biopsy samples were embedded in paraffin blocs with no regard to the orientation of the tissue. The whole blocs were then cut into $5 \mu \mathrm{m}$ sections; random sections were deparaffinized, rehydrated and stained with hematoxylin-eosin.

\section{Evaluation of bronchial tissue morphology}

The slides were examined at one centre, by an experienced blinded evaluator (Qutayba Hamid). Qualitative evaluation (score) of bronchial tissues was performed for the following criteria: general morphology (intact or fragmented tissue, edema, bleeding, fibrosis, crush artefacts, holes), presence or absence of SM bundles, inflammation, cartilage, mucus glands, BM and epithelium integrity. From visual estimation, an overall score was 


\begin{tabular}{|c|c|c|c|c|c|c|c|}
\hline & \multicolumn{2}{|c|}{ Lobar (2 sites) } & \multicolumn{2}{|c|}{ Segmental (3 sites) } & \multicolumn{2}{|c|}{ Subsegmental (1 site) } & \multirow{2}{*}{$\begin{array}{c}\text { All } \\
A+H C(n=153)\end{array}$} \\
\hline & $A(n=24)^{*}$ & $\mathrm{HC}(n=28)$ & $A(n=36)$ & $\mathrm{HC}(\mathrm{n}=39)$ & $A(n=12)$ & $\mathrm{HC}(n=14)$ & \\
\hline Score $\leq 2$ & 54.2 & 71.4 & 66.7 & 61.5 & 50.0 & 57.1 & 61.7 \\
\hline Smooth muscle bundles & 75.0 & 75.0 & 77.8 & 79.5 & 75.0 & 71.4 & 76.5 \\
\hline Infiltration by inflammatory cells & 83.3 & 64.3 & 77.8 & 59.0 & 83.3 & 57.1 & - \\
\hline Cartilage & 4.2 & 3.6 & 11.1 & 10.3 & 33.3 & 50.0 & - \\
\hline Mucus glands & 25.0 & 35.7 & 36.1 & 38.5 & 58.3 & 21.4 & - \\
\hline Thickened basement membrane & $79.2^{\dagger}$ & 50.0 & $77.8^{\ddagger}$ & 35.9 & 50.0 & 35.7 & - \\
\hline Epithelium integrity & $29.2^{\dagger}$ & 57.1 & 44.4 & 38.5 & 33.3 & 28.6 & 40.5 \\
\hline
\end{tabular}

Data are expressed as a percentage of tissue samples meeting the selected criteria. *Total number of bronchial tissue samples obtained for the different sampling sites in each group; ${ }^{\dagger} P \leq 0.05,{ }^{\ddagger} P \leq 0.01$ when comparing asthma $(A)$ with healthy control $(H C)$

given to each biopsy according to the following scale: 1 , excellent morphology; 2, good quality; 3, partially suitable for assessment; 4, poor quality; and 5, not suitable for assessment. Quantitative measurements were performed on the biopsy sections to determine total surface area $\left(\mathrm{mm}^{2}\right)$, SM surface area $\left(\mathrm{mm}^{2}\right)$, length of intact BM (mm) and length of intact epithelium $(\mathrm{mm})$. These measurements were performed on an analysis system (Image Pro Plus software, Media Cybernetics, USA). From those parameters, percentage of SM surface area/total surface area and percentage of intact epithelium/length of BM were calculated.

\section{Data analysis}

For the clinical characteristics of the subjects, a Student's $t$ test was performed on the different lung function data. For total surface area, SM area, BM length and intact epithelium length, the sample was excluded from statistical analysis when the specific structure was missing in the bronchial mucosa. To evaluate the frequency of biopsy samples containing the different studied structures, a $\chi^{2}$ test was performed. The parameters studied were log-transformed for total surface area, SM area and basal membrane length. A square root transformation was used to analyze length of intact epithelium $\left(\mathrm{mm}^{2}\right)$, and an arcsine on the square root was used for values in percentage. Data were presented as mean and 95\% CI after the back transformations. For each outcome variable, a three-way ANOVA mixed model was used to analyze two experimental fixed factors; one factor associated with the comparison between groups (healthy controls versus asthmatic subjects), and one linked to the sampling sites. This level was analyzed as a repeated-measures factor, with an interaction term between the fixed factors added to the statistical model. A heterogeneous compound symmetric structure was used to measure the dependence among repeated measurements. The Tukey's multiple comparison technique was applied a posteriori to the ANOVA. The univariate normality assumptions were verified with the Shapiro-Wilk test. The Brown and Forsythe's variation of Levene's test statistics was used to verify the homogeneity of variances, and multivariate normality was verified using the Mardia test. The results were considered to be significant for values of $\mathrm{P} \leq 0.05$. The data were analyzed using the statistical package program SAS version 8.2 (SAS Institute Inc, USA).

\section{RESULTS}

Bronchoscopy and bronchial biopsies were well tolerated, and the subjects experienced no major side effects, except for minor bleeding for a few volunteers. No abnormalities or signs of infection were observed on examination of the bronchi for any of the subjects. From the 27 volunteers, 153 biopsy attempts of a total of $162(94.4 \%)$ had enough tissue to be processed from the different sampling sites (Table 2). The remaining $5.6 \%$ corresponded to missed attempts, mucous accumulations or fragmented epithelial scrapings.

Qualitative data are described in Table 3. Microscopic examination of the biopsy samples showed that 95 of the 153 suitable bronchial samples $(61.7 \%)$ were scored with a good to excellent quality (score of 2 or less). No statistical difference was observed for the quality of the biopsy samples (assessed by the scoring system) between asthmatic and healthy subjects or among the different sites. SM bundles were observed in $76.5 \%$ of the bronchial biopsies; similar proportions were observed between asthmatic and healthy subjects, and among the different sampling sites. For all sampling sites, there was a trend toward higher percentage of biopsies with inflammatory cell infiltration for asthmatic subjects than for healthy controls, although it did not reach statistical significance $(P>0.05)$. Presence of cartilage was increased in the subsegmental carinae compared with the lobar and segmental biopsy specimens for both asthmatic and healthy subjects. From the larger bronchi to the smaller bronchi, the percentage of biopsy specimens containing mucus glands was increased for asthmatic subjects $(25.0 \%, 36.1 \%$ and $58.3 \%$ for lobar, segmental and subsegmental, respectively). This pattern was not observed for healthy controls. There were significantly more biopsy samples with an apparent thickened BM for asthmatic subjects than for healthy controls $(79.2 \%$ versus $50.0 \%$, respectively, for the lobar carinae, $\mathrm{P}<0.05$; and $77.8 \%$ versus $35.9 \%$, respectively, for the segmental carinae, $\mathrm{P}<0.01)$. Only 62 bronchial samples of the 153 processed samples $(40.5 \%)$ had intact epithelium. There was significantly more intact epithelium at the lobar sampling site for the healthy controls compared with the asthmatic subjects $(\mathrm{P} \leq 0.05)$.

Figure 1 shows the quantitative measurements performed on the bronchial biopsy specimens from asthmatic and healthy subjects. There was no difference in the total surface area of the biopsy between both groups of subjects (Figure 1A). Moreover, the sampling site has no influence on this parameter. From the $76.5 \%$ of biopsy specimens containing SM bundles, SM area was significantly lower in biopsy samples from healthy subjects at the subsegmental level $\left(0.07 \pm 0.02 \mathrm{~mm}^{2}\right)$ than at the lobar $\left(0.12 \pm 0.02 \mathrm{~mm}^{2} ; \mathrm{P}<0.05\right)$ and segmental sites $\left(0.20 \pm 0.07 \mathrm{~mm}^{2}\right.$; $\mathrm{P}<0.05)$ from the same group, and from all sampling sites compared with the asthmatic subjects $\left(0.15 \pm 0.03 \mathrm{~mm}^{2}\right.$ and $0.23 \pm 0.08 \mathrm{~mm}^{2}$ for the lobar and segmental carinae, respectively, 


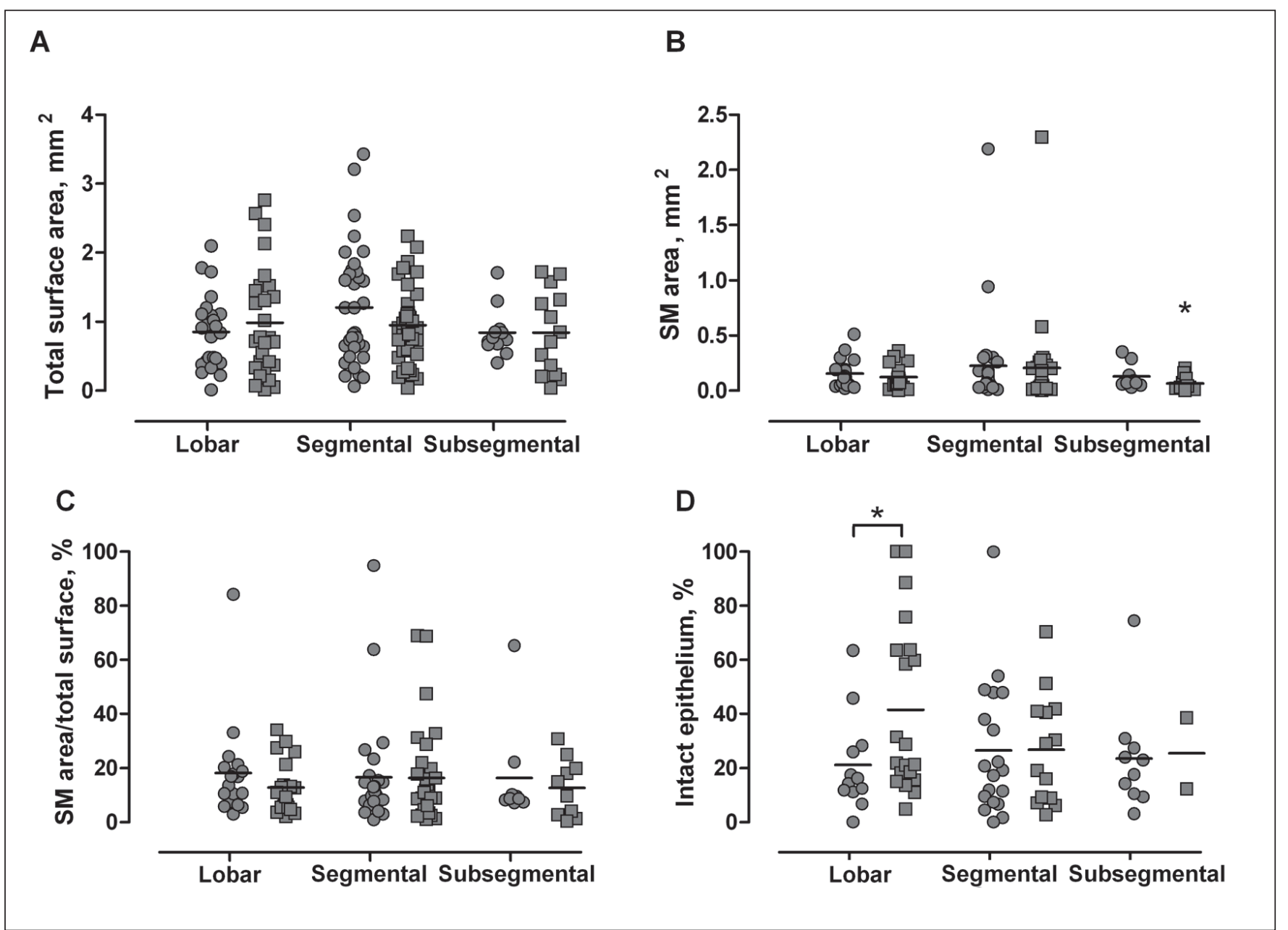

Figure 1) Quantitative measurements of bronchial biopsy specimens, according to the sampling site and group of interest. The circles and squares represent the asthmatic subjects and the healthy controls, respectively. Mean values are represented by horizontal bars. A No difference in total surface area of the bronchial biopsy samples from the different sampling sites and group of subjects. B Smaller amounts of smooth muscle (SM) area in bronchial biopsies obtained from healthy controls at the subsegmental level, compared with all other groups. C No statistical difference in the percentage of SM arealtotal surface for the different sampling sites and group of subjects. D Increased percentage of intact epithelium at the lobar carinae from healthy controls compared with asthmatic subjects. $* P<0.05$

$\mathrm{P}<0.01$; and $0.13 \pm 0.04 \mathrm{~mm}^{2}$ for the subsegmental carinae, $\mathrm{P}<0.05$ ) (Figure 1B). However, the relative percentage of SM area/total surface was not significantly different between the two groups (Figure 1C). From the $40.5 \%$ of the biopsies presenting intact epithelium, the percentage of intact epithelium was significantly higher in healthy control samples from the lobar carinae compared with the asthmatic subjects $(41.6 \pm 7.0 \%$ and $21.1 \pm 5.1 \%$, respectively; $\mathrm{P}<0.05)$; this difference was not observed in segmental and subsegmental samples (Figure 1D).

\section{DISCUSSION}

The determination of quality parameters for bronchial biopsies and an evaluation of their structural components are critical, considering that many research centres use bronchial biopsies to study remodelling and airway inflammation, as well as to establish primary bronchial cell cultures. Very few reports emphasize the importance of the tissue quality obtained from bronchoscopy (5), nor the percentage of sample attempts that provide valuable tissue $(13,14)$.
The present study shows that, from a pool of six bronchial biopsy specimens taken from three different sampling sites, tissue samples were obtained in approximately all attempts (94.4\%) and, according to the scoring system, excellent to good biopsy quality was obtained in two-thirds of the successful attempts in asthmatic and healthy subjects (61.7\%). There are a limited number of carina that allow tissue sampling. Lobar carina (third generation of bronchi) are often too wide to grip and successfully cut submucosal tissue, except for the right middle lobe. Most subsegmental carina (fifth generation of bronchi) are often too thin to provide valuable amounts of tissue. Segmental carina of the lower lobes (fourth generation of bronchi) usually provide the most numerous and valuable sampling sites. Consequently, we decided to take two samples of the right middle lobe carinae, three samples of the segmental carina and one sample of the subsegmental carina of the lower lobes. The choice of a specific carina was of relatively little importance because of the very slight variations among the sampling sites, suggesting the homogeneity of the tissue specimens. It should be noted that inflammatory cell infiltration is not 
specifically measured by hematoxylin-eosin staining, making it difficult to quantify the inflammation in the bronchial mucosa. The frequency of bronchial biopsies with cartilage and mucus glands is increased as the tissue samples are obtained further down the airway tree. The increase may be due to the size of the biopsied carinae - the smaller the carina, the deeper the forceps can grip into the mucosa and reach cartilage or mucus glands. The number of biopsy samples with a thickened BM were statistically different between asthmatic and healthy subjects in larger airways (third and fourth generations of bronchi). Also described as accumulation of extracellular proteins (mainly collagen and fibronectin), thickening of the BM has been reported to be a characteristic feature in the early stages of the disease (15) and may possibly be used to differentiate asthma from chronic obstructive pulmonary disease (16).

From the quantitative measurements, significant differences between asthmatic and healthy controls were observed for SM area and percentage of intact epithelium. Subsegmental samples from healthy subjects exhibited substantially smaller amounts of SM than all of the other sampling sites and in comparison with those from asthmatic subjects. However, when normalizing the SM area for the total surface of the biopsy, no statistical difference was observed. These results are in accordance with Benayoun et al (10), reporting no difference in the percentage of SM area in patients with intermittent asthma compared with control subjects (a very similar group of subjects compared with those in the present study). The only marked difference between the two studies concerns the values of the percentages $(8.3 \%$ versus $17.1 \%$ for asthmatic subjects and $9.4 \%$ versus $14.1 \%$ for healthy controls, respectively, for Benayoun's study versus the present study). The difference may be due to the use of different forceps by the bronchoscopists; the FB-15C-1 forceps from Olympus are large and might grip larger portions of tissue than other types of forceps. This feature could also account for the higher percentage of SM area in the

\section{REFERENCES}

1. Elston WJ, Whittaker AJ, Khan LN, et al. Safety of research bronchoscopy, biopsy and bronchoalveolar lavage in asthma. Eur Respir J 2004;24:375-7.

2. Azzawi M, Bradley B, Jeffery PK, et al. Identification of activated $\mathrm{T}$ lymphocytes and eosinophils in bronchial biopsies in stable atopic asthma. Am Rev Respir Dis 1990;142:1407-13.

3. Beasley R, Roche WR, Roberts JA, Holgate ST. Cellular events in the bronchi in mild asthma and after bronchial provocation. Am Rev Respir Dis 1989;139:806-17.

4. Hamid Q, Azzawi M, Ying S, et al. Expression of mRNA for interleukin-5 in mucosal bronchial biopsies from asthma. J Clin Invest 1991;87:1541-6.

5. Jeffery P, Holgate S, Wenzel S. Methods for the assessment of endobronchial biopsies in clinical research: Application to studies of pathogenesis and the effects of treatment. Am J Respir Crit Care Med 2003;168:S1-17.

6. Goulet F, Boulet LP, Chakir J, et al. Morphologic and functional properties of bronchial cells isolated from normal and asthmatic subjects. Am J Respir Cell Mol Biol 1996;15:312-8.

7. Ma X, Cheng Z, Kong H, et al. Changes in biophysical and biochemical properties of single bronchial smooth muscle cells from asthmatic subjects. Am J Physiol Lung Cell Mol Physiol 2002;283:L1181-L9.

8. Laprise C, Sladek R, Ponton A, Bernier MC, Hudson TJ, Laviolette M. Functional classes of bronchial mucosa genes that are differentially expressed in asthma. BMC Genomics 2004;5:21.

9. Bousquet J, Jeffery PK, Busse WW, Johnson M, Vignola AM. Asthma. From bronchoconstriction to airways inflammation and remodeling. Am J Respir Crit Care Med 2000;161:1720-45. present study. Epithelial integrity was found to be different between asthmatic and healthy subjects. Shedding of the surface epithelial cells and modified phenotype of basal cells have been reported in the histological section of bronchial biopsies from asthmatic subjects (17). In the present study, the percentage of intact epithelium was increased, with statistical significance, at the lobar sampling site for the healthy controls compared with the asthmatic subjects. These results corroborate the epithelial shedding and fragility observed in asthma (17-19). Epithelial cells are directly exposed to not only allergens and air pollutants, but also to inflammatory cytokines, proteases secreted by various leukocytes and structural cells that compose the bronchial mucosa. Damage to the epithelial layer can be involved in maintaining the inflammation and encouraging the remodelling process observed in asthma, even in the early stages of the disease.

\section{CONCLUSION}

Three to four bronchial tissue samples with excellent quality and valuable morphology can be obtained from a pool of six bronchial biopsy attempts, taken from the bronchial subcarinae of the third to fifth generations in both asthmatic and healthy subjects. These biopsies provide sufficient tissue for morphological analysis of bronchial mucosa, for SM analysis, and eventually, for primary cell culture.

ACKNOWLEDGEMENTS: The authors thank Luce Trépanier for recruitment and clinical evaluation of the subjects, nurses at the bronchoscopy departments of the Laval Hospital and the Montreal Thoracic Institute, Marie-Claude Bernier, Martine Paquette and Doris Cantin for technical assistance, and Serge Simard for statistical analysis.

FUNDING: This study was supported by Réseau en Santé Respiratoire of the Fonds de la recherche en santé du Québec.

10. Benayoun L, Druilhe A, Dombret MC, Aubier M, Pretolani M. Airway structural alterations selectively associated with severe asthma. Am J Respir Crit Care Med 2003;167:1360-8.

11. Tang ML, Wilson JW, Stewart AG, Royce SG. Airway remodelling in asthma: Current understanding and implications for future therapies. Pharmacol Ther 2006;112:474-88.

12. Standards for the diagnosis and care of patients with chronic obstructive pulmonary disease (COPD) and asthma. This official statement of the American Thoracic Society was adopted by the ATS Board of Directors, November 1986. Am Rev Respir Dis 1987;136:225-44.

13. Regamey N, Hilliard TN, Saglani S, et al. Quality, size, and composition of pediatric endobronchial biopsies in cystic fibrosis. Chest 2007;131:1710-7.

14. Saglani S, Payne DN, Nicholson AG, Scallan M, Haxby E, Bush A. The safety and quality of endobronchial biopsy in children under five years old. Thorax 2003;58:1053-7.

15. Jeffery PK. Remodeling in asthma and chronic obstructive lung disease. Am J Respir Crit Care Med 2001;164:S28-S38.

16. Chu HW, Halliday JL, Martin RJ, Leung DY, Szefler SJ, Wenzel SE. Collagen deposition in large airways may not differentiate severe asthma from milder forms of the disease. Am J Respir Crit Care Med 1998;158:1936-44.

17. Holgate ST, Lackie PM, Davies DE, Roche WR, Walls AF. The bronchial epithelium as a key regulator of airway inflammation and remodelling in asthma. Clin Exp Allergy 1999;29(Suppl 2):90-5.

18. Shahana S, Bjornsson E, Ludviksdottir D, et al. Ultrastructure of bronchial biopsies from patients with allergic and non-allergic asthma. Respir Med 2005;99:429-43.

19. Laitinen A, Laitinen LA. Airway morphology: Epithelium/basement membrane. Am J Respir Crit Care Med 1994;150:S14-S7. 


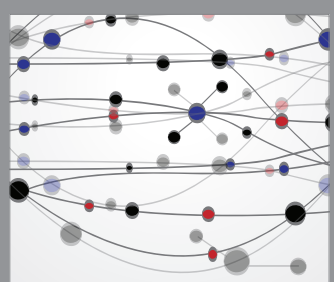

The Scientific World Journal
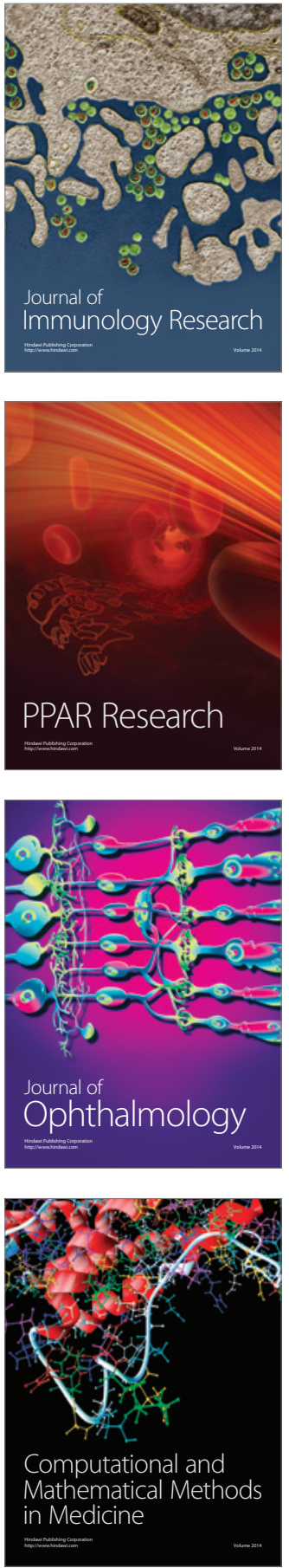

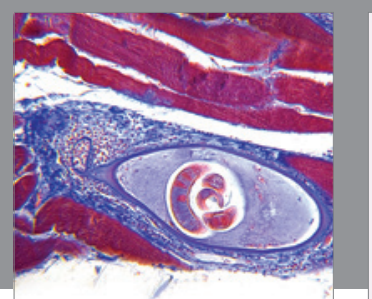

Gastroenterology Research and Practice

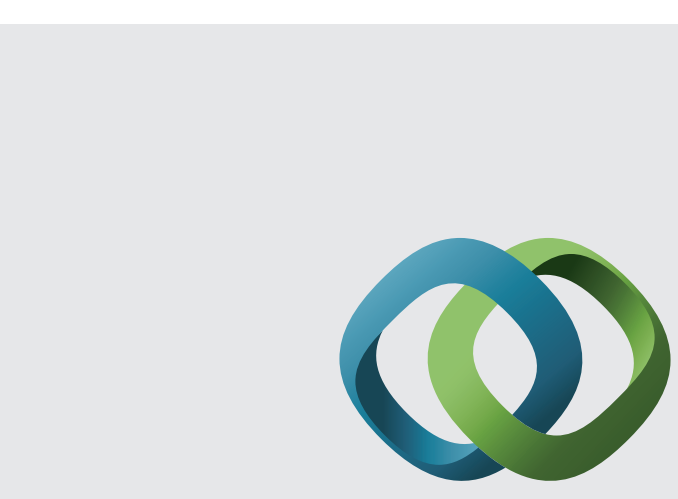

\section{Hindawi}

Submit your manuscripts at

http://www.hindawi.com
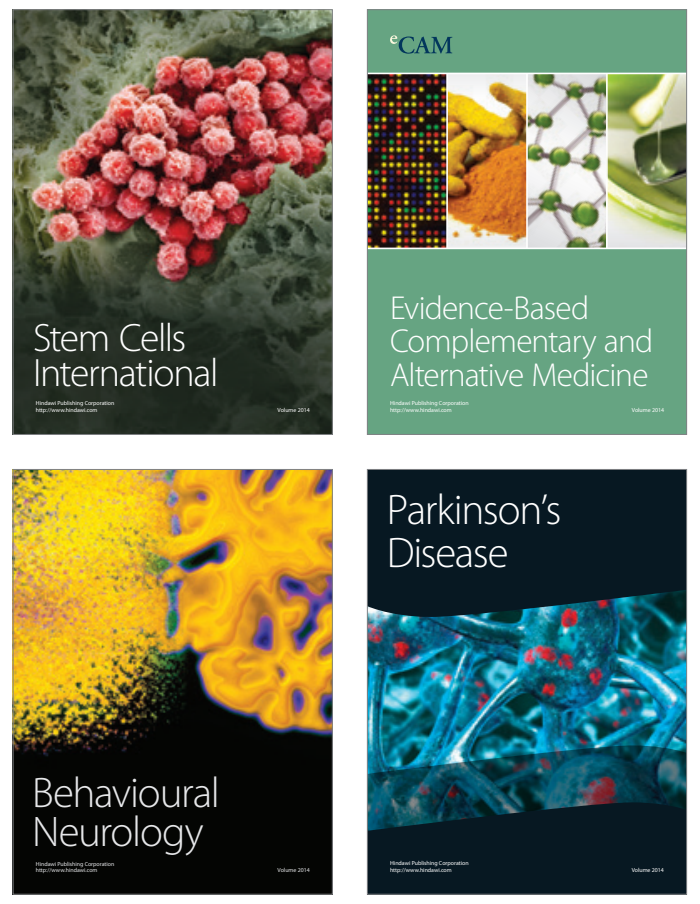
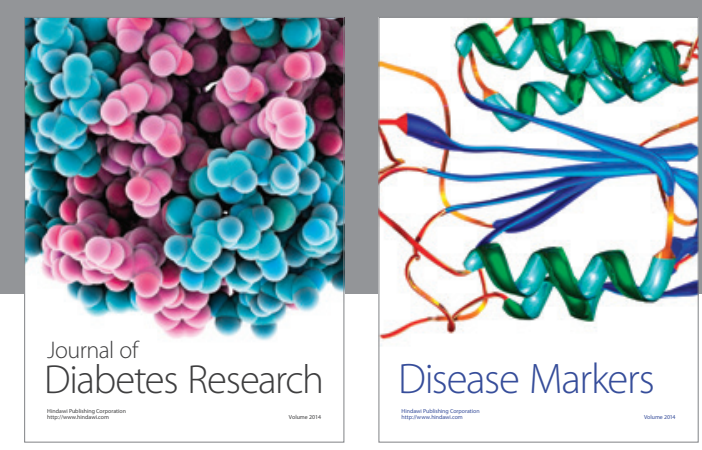

Disease Markers
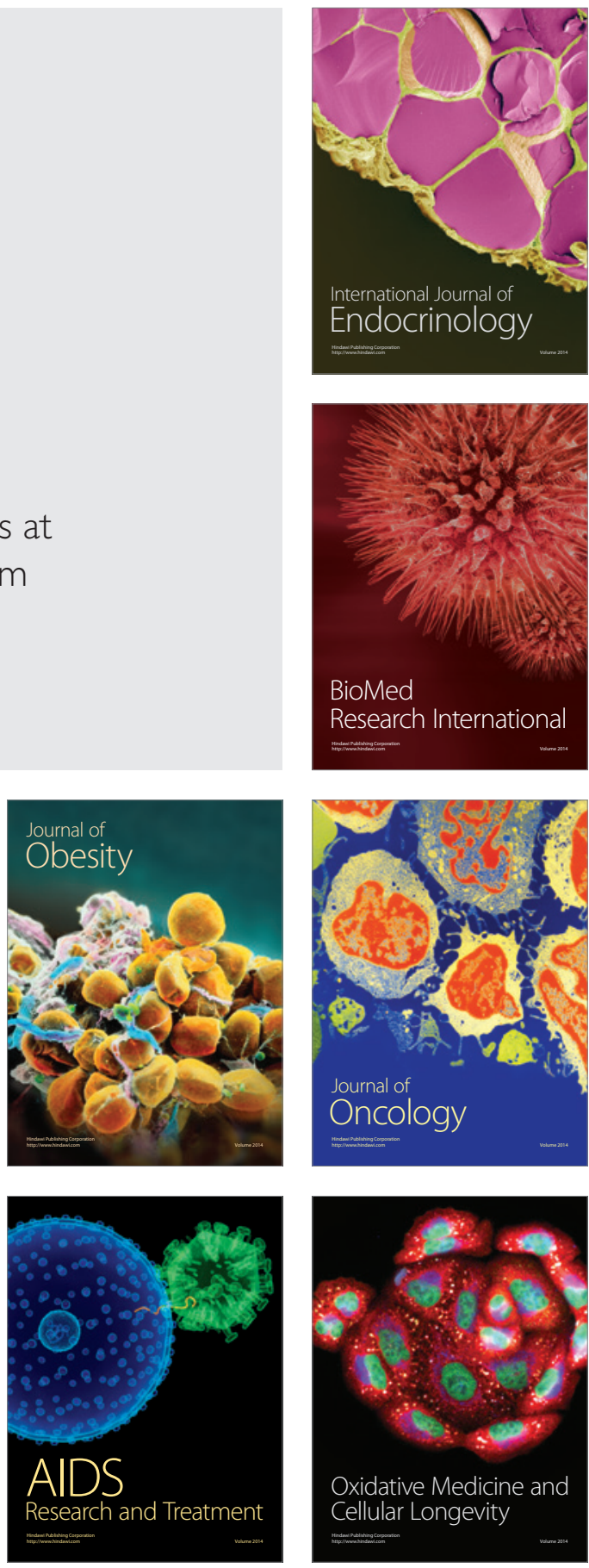